\title{
Process Based Feasible Geo-engineering Measure to Counter Global Warming
}

\section{R. C. Yadav*}

Central Soil and Water Conservation Research and Training Institute, Research Centre, Agra, 282006, Uttar Pradesh, India

\begin{abstract}
A process developed for eradication of polluting gas namely carbon dioxide, which becomes killer gas under high concentration in open wells etc and patented. It is described here as one of its manifestation for application as geo-engineering measure to counter global warming. The process and product named geoact ca-5, is simple and feasible to organize and commission its application to eradicate without any risk of side adverse effect or after effects, the GHGs such as $\mathrm{CO}_{2}$ and $\mathrm{SO}_{2}$, which become main cause of global warming and acid rain, respectively, can be eradicated. This method overcomes all likely limitations associated with other geo-engineering measures mooted to counter global warming. The new method is supported by the research data. Delphi method for multiple attribute evaluation of different geo-engineering alternatives thought over to be applicable to counter global warming, fulfilment of requirements of an ideal innovation for is diffusion and fulfilment of role of patent etc go in strong favour of adoption of this method over the others. Another manifestation viz. entrap and eradicate devised in the study will go long way in automatic eradication of excess $\mathrm{CO}_{2}$ without any foreseen danger of over eradication. Large scale application of geoact ca-5 can be implemented by peoples' participation. Some research areas are identified.
\end{abstract}

Keywords: Acid rain; Eradication of polluting gas; Geo-engineering measures to counter global warming; Polluting gas; Peoples' participation; Tree plantation

\section{Introduction}

Global warming and climate change are topics of concern world over. The global warming potential is the warming impact of a green house gas (GHG). The green house gases are trace gases present in atmosphere that control energy flow in the atmosphere by absorbing infra-red radiation. Some GHGs occur naturally while others result from human activities called as anthropogenic GHG. There are six GHGs under the Kyoto Protocol i.e. carbon dioxide $\left(\mathrm{CO}_{2}\right)$, methane $\left(\mathrm{CH}_{4}\right)$, nitrous oxide $\left(\mathrm{N}_{2} \mathrm{O}\right)$, hydroflurocarbons (HFCs), per fluorocarbons (PFCs), and sulphur hexafluoride $\left(\mathrm{SF}_{6}\right)$. The $\mathrm{CO}_{2}$ is the most important GHG released by human activities. The $\mathrm{CO}_{2}$ is taken as reference case and hence it always has global warming potential (GWP) of 1. The GWP changes with time and IPCC has suggested using 100 year GWP for comparison purposes. The 100 year GWP for the six trace GHGs are: $\mathrm{CO}_{2}, 1 ; \mathrm{CH}_{4}, 21 ; \mathrm{N}_{2} \mathrm{O}, 310$; HFCs, 150-11700; PFCs, 650-9200 and $\mathrm{SF}_{6}, 23900$.

Figure 1 shows the $\mathrm{CO}_{2}$ releasing anthropogenic sources. Industries, power plants, marshy lands, paddy fields, lakes, ponds and animals are the major contributors. This pictorial view reveals occurrence of $\mathrm{CO}_{2}$ in the bottom layers that provides an opportunity for easy eradication. $\mathrm{CO}_{2}$ has maximum density among the gases and it tries to displace the other light gases up and settles in the bottom most layer of the space. The natural respiratory releases are not accounted for. Likewise, Figure 2 shows the $\mathrm{CO}_{2}$ in sink terms i.e. used by plants and vegetation including forests and sea. The plants do not perform photosynthesis in absence of the Sun light that means the sink by plant becomes un functional and there occurs flooding of $\mathrm{CO}_{2}$ on rainy, cloudy and Sun shine less days and during the nights. Largely the concentration of the $\mathrm{CO}_{2}$ is the maximum during foggy and cloudy mornings that too near the ground.

Levels of heat trapping green house gas viz. Carbon dioxide has been increasing steadily since 1960 due to combustion of fossil fuels viz. coals, oils and natural gas. The net effects are noticed in alteration of climate of regions; causing hydrologic extremes of floods and droughts, melting glaciers and rising of sea level etc. Several researchers have predicted by mathematical models, the rise in temperature and

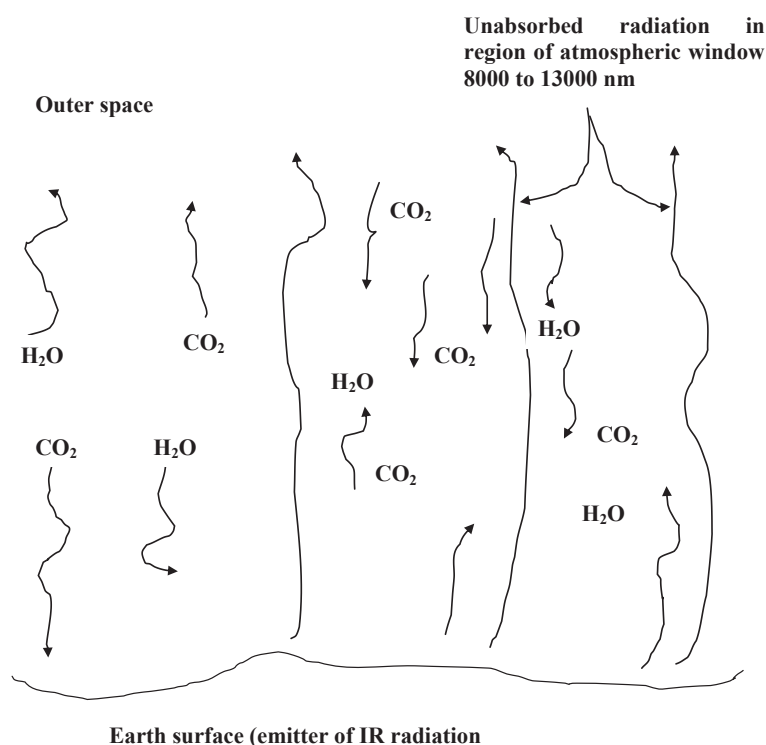

Figure 1: The green house effect (After De ,2004).

*Corresponding author: Ex Head and Principal Scientist (Retd.), Central Soil and Water Conservation Research and Training Institute, Research Centre, Agra, 282006, Uttar Pradesh, India, E-mail: ramcyadav@rediffmail.com

Received December 19, 2012; Accepted March 18, 2013; Published March 21 2013

Citation: Yadav RC (2012) Process Based Feasible Geo-engineering Measure to Counter Global Warming. Hydrol Current Res S1:004. doi:10.4172/2157-7587. S1-004

Copyright: (c) 2012 Yadav RC. This is an open-access article distributed under the terms of the Creative Commons Attribution License, which permits unrestricted use, distribution, and reproduction in any medium, provided the original author and source are credited. 


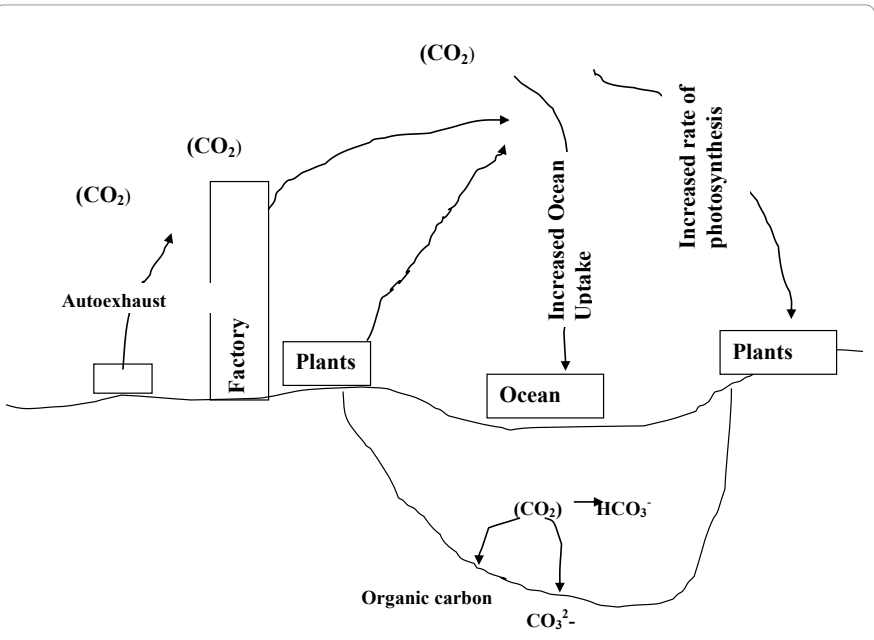

Figure 2: Sources and Sinks of Carbon Dioxide.

indicated possibility of rise in sea-level leading to submergence of low-lying countries, rapid destruction of ozone layer above Antarctica in 1985 and chlorofluorocarbon (CFC's) free the chlorine bind with oxygen. Wide spread effects of global warming are noticed in form of extreme occurrence of floods and droughts. The severity of global warming in the Polar Regions and damage to the ozone layer are of pondering concern. Baskin [1] presented details of various geoengineering approaches, their advantages and likely disadvantages, which need national and international backing for their applications and generation of research base. Although, among the referred geoengineering measures viz. planting trees, fertilizing oceans, and other schemes, have research base, several other measures namely, placement of sun shield in to atmosphere, adding soot or dust to the atmosphere and adding sulphur particles above ocean are speculative on their effects and lack research base. The effectiveness and longevity of effects of the geo-engineering measures are not free from scientific debate. Further, the measures largely remain far from reach with respect to feasibility of application and cost.

The usual concentration of $\mathrm{CO}_{2}$ in the atmosphere is $0.033 \mathrm{ppmv}$ (Table 1) which is generally not noticed as it is non lethal, colourless and odourless. However, at its higher concentration, it becomes killer gas. In India many deaths in open wells that occurred due to this problem were reported by police stations frequently. In eradication of lethal concentration of this killer gas viz. $\mathrm{CO}_{2}$ a low cost process based method was developed. The method is free from scientific flaw, feasible to apply results conforming instant eradication and lends itself to various manifestations to eradicate carbon dioxide and sulphur dioxide, which are major polluting gases, both produced anthropological and that produced by non anthropological sources. The new eradicative process does not cause the after effects or any side effect or several disadvantages associated with other geo-engineering measures thought over to counter the global warming [1]. Yadav [2] presented utility and application of this manifestation for combating problem of acid rain. Pollution in open or enclosed columnar staking of polluting gases viz. $\mathrm{CO}_{2}$ and $\mathrm{SO}_{2}$ exist on or off site that cause global warming. The objective of this study was to evaluate this manifestation to counter the global warming and compare in contrast with the known or mooted other geo-engineering measures for this purpose.

Presented here is the comparison with other feasible or non feasible geo-engineering measures thought over to counter global warming and prevention of destruction of ozone layer. Analytical answer to the question for thought and discussion documented by Baskin [1] for example, "Suppose that scientists determine that global warming is occurring and that drought and storms from climate change in the next decade will likely devastate farmlands throughout Africa, Asia and the United States. The experts predict, however, that some areas such as Russia, Scandinavia and Canada may benefit from global warming as crop growing regions shift farther north. Under these circumstances would you favour attempting Geo-engineering Projects? If so which one? What group of individual should have the authority to decide whether to go forward with the project? How should disagreement on the issue between nations be handled? ", are also presented.

\section{Materials and Method}

\section{Chemical reactions}

Polluting gas such as $\mathrm{CO}_{2}$ causes green house effect that restricts reflected light from the Earth, which raises temperature of atmosphere above the Earths' surface. Another problem caused by the other polluting gas such as $\mathrm{SO}_{2}$ is the acid rain [3]. Chemical reactions that cause acid rains are described in detail in http:/en.wikipedia.org/wiki/ Acid rain, [4], Seinfeld and Pandis [5] and Yadav [2].

\section{Experimental details}

Research carried out from 1995 to 2006 for identifying the gas that becomes killer gas in open wells and finding its control measure, lead to development of the process for eradication of polluting gas and grant of patent. Nevertheless, brief description of the method is given here to make the subject of development of the manifestation comprehensible. The research was carried out in a well located close to the forest in deep gullies at Chhalesar, District Agra, Uttar Pradesh, India (78 $-02^{\prime} \mathrm{E}, 27^{\circ}$ $10^{\prime} \mathrm{N}$ and $169 \mathrm{~m}$ above mean sea level). The well was equipped with centrifugal pump installation and incidence presence of a poisonous gas was identified as $\mathrm{CO}_{2}$ by testing it by lighting lantern method. A method was devised to eradicate toxic gas present in the well in Sept 1999.

The problem of occurrence of the killer gas was again noticed on August 23, 2001. These gases were again ascertained by the flaming method of testing. The gases in both the instances were found as the $\mathrm{CO}_{2}$. Continuous flaming essentially requires continuous supply of oxygen and flame will get extinguished in absence of oxygen and presence of carbon dioxide. The level of gas in the well was ascertained by hanging lighting lantern. The lighting lantern got extinguished after reaching some depth. After ascertaining the level of $\mathrm{CO}_{2}$, eradication of gas was carried out by preparing and applying the process. As an extra precaution, another round of the Geoact-Ca5 application was performed to eradicate $\mathrm{CO}_{2}$ emitted by the flaming lantern used for testing of presence of gas during the experimentation. The entire operation of application of the product and process was carried out for eradication of the polluting killer gas in the well in the presence of Scientists, Technical Officers, Technicians, skilled and unskilled

\begin{tabular}{|l|c|}
\hline Types of gases & Composition, ppmv \\
\hline Nitrogen & 78.08 \\
\hline Oxygen & 20.94 \\
\hline Argon & 0.93 \\
\hline Carbon dioxide & 0.033 \\
\hline $\begin{array}{l}\text { Neon, helium, methane, kriptone, xenon, hydrogen, } \\
\text { nitrous oxide, water vapour, smoke and dust }\end{array}$ & Traces \\
\hline
\end{tabular}

Table 1: Composition of gases in the biosphere. 
Citation: Yadav RC (2012) Process Based Feasible Geo-engineering Measure to Counter Global Warming. Hydrol Current Res S1:004. doi:10.4172/2157-7587.S1-004

Page 3 of 6

labourers working at the Research Centre (Table 2). Complete eradication of the gas was verified up to the full satisfaction of those present at the site. Next day the pump repairing work was completed and irrigation started without any trouble.

\section{Assessment of suitability by multiple attribute consideration of the geo-engineering measures}

Delphi method is a progressive procedure to develop reasoned consensus from different perspective and opinions [6]. The factors listed in Table 3 were assigned weightage. Four factors viz. free from land need, feasibility, lowest cost, and no risk were assigned equal importance (weightage of 100). The other four factors namely, free from side effect, free from after effect, research base and scope for peoples' participation were assigned again equal weightage of 50 each.
The weightage factors were normalized as per the Delphi method. The sums of weighted performance for the attributes were evaluated. The highest sum of the weighted attributes was taken as choice for selecting measure for application.

\section{Results}

Flaming lantern when lowered in the well got extinguished that confirmed presence and level of toxic and suffocating killer gas in the well. The lantern flamed only up to some depth in the well; it indicated type and level of existence of gas. Extinguishing of lantern confirmed that the gas was $\mathrm{CO}_{2}$. Table 2 contains details of well and various operations. Gas was almost full in the well as indicated by the flaming lantern and another strong flaming object lowered in the well that got extinguished.

\begin{tabular}{|c|l|c|c|}
\hline S.No & Particulars & Quantity & Units \\
\hline 1 & Diameter of well & $\mathrm{m}$ \\
\hline 2 & Depth of well & $\mathrm{m}$ \\
\hline 3 & Level of flaming lantern & $\mathrm{m}$ \\
\hline 4 & Level of strong falme extinguished & $\mathrm{m}$ \\
\hline 5 & Level of gas from the top & $\mathrm{m}$ \\
\hline 6 & Level of gas after first round of application of Geoact-Ca5 & $\mathbf{m}$ \\
\hline 7 & Level of gas after second round of Geoact - Ca5 application & $\mathrm{m}$ \\
\hline 8 & Gas eradication rate per round & $\mathrm{m}$ \\
\hline 9 & Cost of gas eradication per instance of gas presence in well & $\mathrm{m}$ \\
\hline
\end{tabular}

1US $\$=$ INR 48/ (Approximate)

Table 2: Details of particulars of well and eradication operation.

\begin{tabular}{|c|c|c|}
\hline Proposal & Benefit & Drawbacks \\
\hline Planting trees & $\begin{array}{l}\text { Trees work as carbon sink. If grown, trees will provide fuel } \\
\text { for electric powerplants that would otherwise use coal. }\end{array}$ & $\begin{array}{l}\text { Massive area of land would be required. Many trees would require } \\
\text { fertilizer and irrigation, which might deplete scarce water supply and } \\
\text { increase pollution. Importing non native trees attract non native insect } \\
\text { and other life that would disrupt the native ecosystem. } \\
\text { Though not visualized by many conservationists, the trees would cause } \\
\text { temporary } \mathrm{CO}_{2} \text { flooding during prolonged rainy, cloudy and winter } \\
\text { sunshine less days. }\end{array}$ \\
\hline $\begin{array}{l}\text { Stimulating phytoplankton growth } \\
\text { by dumping iron in to ocean }\end{array}$ & $\begin{array}{l}\text { More phytoplankton could help reduce global warming as } \\
\text { some } \mathrm{CO}_{2} \text { from the earth's atmosphere is absorbed by } \\
\text { plants,that eventually sink in the sea bed. }\end{array}$ & $\begin{array}{l}\text { The plan would require fertilizing large area of ocean and effort would } \\
\text { probably not last for long. Excess phytoplankton growth would likely } \\
\text { disrupt ocean food chain or cause other harmful effect. Bacteria feeding } \\
\text { on dead phytoplankton might remove large amount of oxygen from the } \\
\text { water. } \\
\text { Such micro organisms will also emit more respiratory } \mathrm{CO}_{2} \text {, especially } \\
\text { during sunshine less periods. }\end{array}$ \\
\hline $\begin{array}{l}\text { Adding soot or dust to the } \\
\text { atmosphere }\end{array}$ & $\begin{array}{l}\text { Soot and dust would help reduce global warming by blocking } \\
\text { some sunlight. }\end{array}$ & $\begin{array}{l}\text { The effect would not last long and dust would require constant supply. } \\
\text { Dust particle in the atmosphere might provide additional surface } \\
\text { for ozone destroying chemical reactions, leading to greater ozone } \\
\text { depletion. The effect would not be uniform around globe. }\end{array}$ \\
\hline $\begin{array}{l}\text { Launching sunshield in the } \\
\text { atmosphere. }\end{array}$ & $\begin{array}{l}\text { The sunshield could help slow global warming as the new } \\
\text { clouds block and reflect some sun lights. }\end{array}$ & $\begin{array}{l}\text { To be effective the sunshield would be so large that they would be very } \\
\text { expensive, difficult to launch, and difficult or impossible to control. }\end{array}$ \\
\hline $\begin{array}{l}\text { Adding sulphur particles to the } \\
\text { air above ocean to make cloud } \\
\text { formation there. }\end{array}$ & $\begin{array}{l}\text { The particles could help slow global warming as new } \\
\text { particles block and reflect some sunlight. }\end{array}$ & $\begin{array}{l}\text { The sulphur particles might wash back to the earth in form of acid rain, } \\
\text { killing marine life and harming plants. The effect would not be uniform } \\
\text { around globe. }\end{array}$ \\
\hline $\begin{array}{l}\text { This method, "Process for } \\
\text { eradication of polluting gas" ** }\end{array}$ & $\begin{array}{l}\text { It is simple, feasible, eradicates } \mathrm{CO}_{2} \text { instantly and converts } \\
\text { in to inert materials. It is applicable for eradication both at } \\
\text { site and off site polluting gases. It can be applied without } \\
\text { use of extra power, electricity, and at remote sites. Various } \\
\text { manifestations are devised to eradicate the polluting gas } \\
\text { on land terrains forests, in lakes, ponds, marshy land, } \\
\text { glaciers ecosystem which can be easily accessed. opensky } \\
\text { and enclosures such as cave, wells, aero plane, cabins, } \\
\text { basements rooms and cinema halls etc. }\end{array}$ & $\begin{array}{l}\text { It has no foreseen limitations and side effects. } \\
\text { It can be applied as per need after noticing any occurrence of } \\
\text { concentration becoming a killer gas. } \\
\text { Further, this method eliminates several limitations associated with other } \\
\text { geo-engineering methods describe in this table. }\end{array}$ \\
\hline
\end{tabular}

- The source of information given in table for other than the last method are based on information given by Baskin, 1996.

** The Process has been patented.

Table 3: Comparative benefits and drawbacks of geo-engineering proposal to counter global warming. 
Rate of eradication of the gas was about $7 \mathrm{~m} /$ round of eradication process performed. It completely eradicated the $\mathrm{CO}_{2}$ at the experimental site. The lantern kept flaming in the well that confirmed complete eradication of the $\mathrm{CO}_{2}$ from the well. The cost of material used for eradication was just Rs 5 only (10 cent approximately)/event of complete eradication.

The first round of operation reduced level of $\mathrm{CO}_{2}$ to almost half of the level it was present in the well. Second round completely eradicated $\mathrm{CO}_{2}$ from the well. The $\mathrm{CO}_{2}$ present in the well got converted into non reactive amorphous product and eradicated from the well. When the $\mathrm{CO}_{2}$ got eradicated suffocation of persons when entered in the well did not occur and they were able to carry out repairing work as usual. Thus, pumping set could be brought in operation after the rainy season.

The particular gas again reoccurred on $23^{\text {rd }}$ August 2001 in the same well. The gas was noticed by workers who entered for repairing of pumping set as they got suffocated. This incidence was taken as an opportunity for validation of the simple method developed for eradication of the killer gas in the wells in the region. The basic material was again procured from the market. Entire operation was conducted again in presence of scientists, technical officers and workers at the farm to prove the functioning of the process so developed, beyond doubt and full satisfaction of different groups of people. Thus the process works very well to eradicate the gas $\mathrm{CO}_{2}$, which is almost $50 \%$ responsible for causing green house effect to cause global warming.

Although the process has been experimentally demonstrated to eradicate $\mathrm{CO}_{2}$, it is equally applicable for eradication of $\mathrm{SO}_{2}$ leading to formation of $\mathrm{SO}_{3}$ and by converting it in to $\mathrm{CaSO}_{4}$. The $\mathrm{CaSO}_{4}$ works as an amendment in the acid soil. Thus, air pollutant which causes acid rain is converted into a useful product by application of the process.

The new process of eradication of GHGs presented in this study which is manifested later as geoact-ca5 was compared from different aspects as given in Table 3 and 4. Http:/en.wikipedia/ diffusion of innovation [7] prescribed necessary characteristics viz. relative advantage, compatibility, complexity or simplicity, trial ability and observability as important inbuilt charcteristics for diffusion of innovation. All these specific features are intrinsically built in the product and process presented in this study.

The weighted performance of the new process for eradication of polluting gas was the highest (93.76) followed by the tree planting (46.67) to counter global warming (Table 5). Other geo-engineering measures were almost on similar level of performance under the evaluation. Other geo-engineering measure lack on account of performance (under 30) of attributes namely feasibility, cost and involvement of risks.

\section{Discussion}

\section{Discussion of results}

From the chemical reactions involved in the process of air pollution it is clear that $\mathrm{CO}_{2}$ and $\mathrm{SO}_{2}$ can be eradicated by application of the product and process Geoact-Ca5 developed in this study. The web site http:/en.wikipedia.org/wiki/Acid rain [4] reported that $70 \mathrm{Tg}(\mathrm{S})$ per year in the form of $\mathrm{SO}_{2}$ comes from fossil fuel combustion

\section{Geo engineering proposals}

Sending large electrified metal screen in to the upper atmosphere above Antarctica.

Adding propane gas to the upper atmosphere above Antarctica

Destroying the CFC in the atmosphere by blasting them with beams from high power laser mounted on mountain tops.

This process for eradication of polluting gas ${ }^{* *}$

\section{Benefits}

Electron released from the screen will combine with the chlorine atoms for CFC to prevent atoms from destroying ozone.

Propane would react chemically with chlorine atoms and prevent atoms from destroying ozone.

The laser could eliminate CFC before the molecules begin to destroy ozone.

It will have neutral effect on preventing action of CFC. It

will neutralize chlorine atom if suitable manifestation for Nothing is known. application is developed.

- The source of information given in table for other than the last method are based on information given by Baskin, 1996

** The Process has been patented.

Table 4: Benefits and drawbacks of geo-engineering proposal to counter ozone depletition.

\begin{tabular}{|c|c|c|c|c|c|c|c|c|c|}
\hline \multirow[t]{2}{*}{ S.No. } & \multirow[t]{2}{*}{ Attributes } & \multirow[t]{2}{*}{ Weightage } & \multirow[t]{2}{*}{$\begin{array}{c}\text { Normalised } \\
\text { weightage }\end{array}$} & \multicolumn{6}{|c|}{ Alternative geo-engineering measures to counter global warming } \\
\hline & & & & Forestry & $\begin{array}{c}\text { Stimulating } \\
\text { phytoplankton } \\
\text { growth }\end{array}$ & $\begin{array}{l}\text { Adding soot } \\
\text { and dust }\end{array}$ & $\begin{array}{l}\text { Launching sun } \\
\text { shield }\end{array}$ & $\begin{array}{l}\text { Adding sulphur } \\
\text { particles }\end{array}$ & $\begin{array}{l}\text { This method- } \\
\text { Process of } \\
\text { eradication of } \\
\text { polluting gases }\end{array}$ \\
\hline (1) & (2) & (3) & (4) & (5) & (6) & (7) & (8) & (9) & (10) \\
\hline 1 & Free from 1 and need & 100 & 0.1667 & $0(0)$ & $95(15.84)^{* *}$ & $95(15.84)$ & $95(15.84)$ & $95(15.84)$ & $95(15.84)$ \\
\hline 2 & Feasibility & 100 & 0.1667 & $85(14.17)$ & $25(4.17)$ & $25(4.17)$ & $25(4.17)$ & $30(5.00)$ & $100(16.67)$ \\
\hline 3 & Free from excessive cost & 100 & 0.1667 & $50(8.34)$ & $10(1.67)$ & $10(1.67)$ & $10(1.67)$ & $10(1.67)$ & $90(15.00)$ \\
\hline 4 & Free from risk & 100 & 0.1667 & $25(4.17)$ & $20(1.67)$ & $15(2.5)$ & $10(1.67)$ & $10(1.67)$ & $90(15.00)$ \\
\hline 5 & Free from side effect & 50 & 0.0833 & $50(4.17)$ & $10(0.83)$ & $10(0.83)$ & $10(0.83)$ & $10(0.83)$ & $90(7.50)$ \\
\hline 6 & Free from after adverse effect & 50 & 0.0833 & $80(6.66)$ & $40(3.33)$ & $30(2.50)$ & $30(2.50)$ & $20(1.67)$ & $95(7.92)$ \\
\hline 7 & Supported with research base & 50 & 0.0833 & $100(8.33)$ & $10(0.83)$ & $10(0.83)$ & $10(0.83)$ & $10(0.83)$ & $90(7.50)$ \\
\hline \multirow[t]{2}{*}{8} & Scope for peoples' participation & 50 & 0.0833 & $60(5.00)$ & 0 & 0 & 0 & 0 & $100(8.33)$ \\
\hline & Total & 600 & 1.00 & $(46.67)$ & $(26.67)$ & $(28.34)$ & (26.68) & $(27.51)$ & (93.76) \\
\hline
\end{tabular}

$59(15.84)^{\star *}$ Assigned performance score (weighted performance score)

Table 5: Evaluation of multi attribute factors for the geo-engineering alternatives to counter global warming by Delphi technique. 
and industry, $2.8 \mathrm{Tg}(\mathrm{S})$ from wild fires and $7-8 \mathrm{Tg}(\mathrm{S})$ per year from volcanoes. While some efforts have been made to reduce emission of $\mathrm{SO}_{2}$ from combustion of fossil fuels and development of green coal for use in the generation plants, the contribution of $\mathrm{SO}_{2}$ emission by the wild fires and the volcanoes do pose the problem. There have been some ways to reduce the $\mathrm{SO}_{2}$ released by the fossil fuel and combustions viz. wet scrubbing and other developments. There has been no method to reduce the risks of $\mathrm{SO}_{2}$ emissions from natural/accidental causes, where the polluting gas cannot be brought to the controlled reaction chambers. The development of product and process Geoact-Ca5 enables eradication of polluting gases present in the atmosphere insitu as and where is basis.

The cost of materials used is very low, it does not involve electrical energy for product processing and application and facilitates its large scale application. The cost and organizing of activity for coverage of any given area will be proportional to the size of area. For site specific small area eradication, the cost of material and application is very little. Since the problem of acid rain is a global, efforts on eradication when taken on global basis would be very effective.

Scientific reports indicate that lakes are strong contributors of $\mathrm{CO}_{2}$ in the atmosphere [8]. The lakes can be treated to convert $\mathrm{CO}_{2}$ and $\mathrm{SO}_{2}-\mathrm{SO}_{3}$ in at suitable intervals to form $\mathrm{CaCO}_{3}$ and $\mathrm{CaSO}_{4}$, which will improve the quality of water worsened by the acid rain that has already occurred or that may occur intermittently in the intervening period of eradication exercises. Further, set-up has been developed to entrap and eradicate [9] the $\mathrm{CO}_{2}$ in the lake to control the contribution of $\mathrm{CO}_{2}$ by the lakes to the atmosphere.

Methane and nitrous oxides are long lived natural trace gases that account for nearly $20 \%$ anticipated atmospheric global warming. Mosier et al. [10] reported the methane uptake and $\mathrm{N}_{2} \mathrm{O}$ emission by native grass and fertiliser application condition and Majumdar, et al. [11] that in fertilized wheat. The study revealed that nitrogenous fertilizer decrease uptake of methane and increase $\mathrm{N}_{2} \mathrm{O}$ flux to the atmosphere. Desert soils are significant contributors to global $\mathrm{CH}_{4}$ soil sink term [12]. Study also suggested that the magnitude of $\mathrm{CH}_{4}$ consumption by the desert soil could increase substantially if there is net increase in arid region moisture. The contribution of methane is not considered to cause the acid rain. However, it gets converted in to $\mathrm{CO}_{2}$ in due course of time. There is no feasible method to eradicate the problem of methane concentration in the atmosphere, except to reduce its escapes from various ecosystem sources on the Earth to the atmosphere. Lima et al. [13], expressed serious concern about mixing of $\mathrm{CO}_{2}$ in the recovered $\mathrm{CH}_{4}$ from the large dams as an alternative power source that can curb global warming. Accompanying $\mathrm{CO}_{2}$ reduces burning efficiency of $\mathrm{CH}_{4}$ They suggested that if $\mathrm{CO}_{2}$ can be separated by any means from the $\mathrm{CH}_{4}$ it can be released to the atmosphere because it is produced by biogenic sources and not from the fossil fuels. The simple method of eradication of polluting gas presented in the present study will eradicate the $\mathrm{CO}_{2}$ and purify the $\mathrm{CH}_{4}$ to acquire high fuel efficiency. The $\mathrm{CO}_{2}$ eradication is possible, be it released from the fossil fuel or biogenic sources. It is well recognised that presence of $\mathrm{CO}_{2}$ does cause warming. Hence new method for eradication of polluting gas will go long way in reducing global warming. Thus, increased efficiency of burning of methane will reduce its release from the water bodies, which are now known to cause global warming by adding $\mathrm{CH}_{4}$ in the atmosphere.

Likewise similar is the situation of existence of no known method for eradication of nitrous oxide responsible for global warming, except to make mandatory control on reduction of emission from the vehicles. Green fuel (biodiesel) and use of hydroxyl to alter emission characteristics and use of portable devices to collect and dispose of the pollutants have been invented, but all these methods work at the point source and not for the non-point source.

Limitation of sink theory to operate during rainy, cloudy and sunshine free days causing $\mathrm{CO}_{2}$ flooding, not yet visualized by other conservationists, can be overcome by entrap and eradicate method [9]. The $\mathrm{CO}_{2}$ is 1.53 times heavier than air and accumulates in bottom of excavation, normally produced by slow oxidation of coal and sometimes dissolution of lime stones [14]. The sources of generation of $\mathrm{CO}_{2}$ may be any; the Geoact $\mathrm{Ca}-5$ is highly suitable for eradicating the $\mathrm{CO}_{2}$.

Baskin [1] commented for the earlier known or mooted geoengineering control measures as the solution worst than the problem. The fear of over cooling, to plunge new ice age, spotty cooling and warming leading to development of climate extreme and formation of acid rain comprise the risk factors. However, there is no such likely danger with the new process of eradication of polluting gas presented under this study. NAS [1] accepted, the methods of geo-engineering which have not been the optimum solution as risk hedger, to try to come-up with back door in case worst it happens, they kept hope that in next 50 years development to come to counter the problem of global warming and come to the set expectations. The new process for eradication of polluting gas has data base and merit in its application.

Further, the process of eradication of polluting gas and its manifestation can be implemented by peoples' participation. The eradication of the polluting gas by method of entrap and eradicate will remove the excess $\mathrm{CO}_{2}$, which otherwise is problem and there is no risk of over eradication. People living in different ecosystem or in the adjacent area can be prepared help operate the entrap and eradicate the $\mathrm{CO}_{2}$ [9] at sites that can be selected in consideration of air current movement and the emitting sources of polluting gases. Hall and Helmens [15] in their study entitled, "Innovation and diffusion of clean green technology", indicated, on the basis of indirect evidences, the role that patent plays in development and diffusion of green technology; more generally the paper sheds light on performance of hybrid forms of knowledge management that combine open innovation and patenting. Robinson and Smith [16] indicated that for adoption of innovation, moderation in health care spending must be sought in new products and process that use lower cost and materials, staff, equipment and sites of care. Air pollution is known to cause varieties of bad health problems and Governments spend lot of money in the social welfare programs. Thus, the product and process presented here fulfils both the aspects of patent and reduction in cost, material, equipment, staff and selective sites of care, which go in strong favour of diffusion of this innovation.

The Delphi method of evaluation of attributes for decision making revealed the best score of the process for eradication of polluting gas for adoption to counter global warming. There is contrast difference between the weighted magnitudes of performance attributes of this geoengineering measure and other geo-engineering methods applicable to counter global warming. Although, there can be some variations in assigning the attribute performance scores by different opinions, the margin of total score is so large that there will not be any change in the inferences and conclusion arrived at in this study.

\section{Answer to the question/discussion set by Baskin}

The global warming has resulted noticeable extremes of occurrence of hydrologic droughts and floods, change in the usual growing seasons of crops and fruiting trees etc. The flowering and fruiting season gets upset and crop yields get reduced considerably. Likewise, the 
Citation: Yadav RC (2012) Process Based Feasible Geo-engineering Measure to Counter Global Warming. Hydrol Current Res S1:004. doi:10.4172/2157-7587.S1-004

Page 6 of 6

agricultural crop yields suffer due to alteration of setting of monsoonal rainfall, delaying sowing and many times rains spoil standing crops ready for harvesting. Thus, it can be said that global warming has caused reduction in yield of grain and pulse crops and fruit trees leading to universal rise of price of foods and fruits etc. Many oil rich countries have suffered the crunch of food shortage and price rise leading to political unrest [1].

Now the question that countries namely, Russia, Scandinavia and Canada may benefit by way of shift in the cropping areas to the North is to be seen. Assuming that these countries have benefited by shift in their cropping area, a question does arise that why the global warming has really occurred due to increased release of GHGs since 1960 [1]. More agricultural activities have been blamed to promote global warming. Further, it is known fact that global warming is severe in the polar regions. That means more agriculture towards polar region is going to intensify further the global warming that may lead to quick disruption of the ecological balance, which may lead to unforeseen consequences. Thus, it is clear that those countries may benefit little for while, but rest of world will be forced to bear the advanced adverse impact of global warming.

Now the question is that which geo - engineering method should be attempted to counter the global warming? A suitable geo-engineering method should bring visible, quick impact and should be free from the after effect or side effect after implementation. It should not cause excessive cooling that might revert the ice age. This study has shown that eradication of polluting gas by application of Geoact $\mathrm{Ca}-5$ fulfils all the aspects required for making an ideal scheme which can be applied to counter the global warming by peoples' participation. The selective areas suffering the adverse effects of global warming may be attempted first. The experiences so gained will guide about how to go in the best interest of world to extend application of the geoact ca-5. Inter governmental panel on global warming should consider application of Geoact $\mathrm{Ca}$ - 5 by peoples' participation, which involves very low budget and that too can be derived from the carbon trading. The opinion decision followed by collective decision and authoritative decision [7] should be taken at every country level that will bring positive cumulative effect worldwide. As the problem of global warming is caused by individuals, their collective contribution should be enforced to counter the global warming.

\section{Conclusion}

A new geo-engineering measure named application of Geoact $\mathrm{Ca}-5$ is presented here in this study, which is free from many limitations associated with different geo-engineering methods thought over to be applied to counter global warming. The method is free from scientific flaw, it is feasible, involves very low cost and lends itself for various manifestation for application in different ecosystems which are known to emit the GHGs leading to cause global warming. Delphi method for evaluation of attributes associated with different alternatives geo-engineering measures to counter global warming, grant of patent and low cost, low requirement of materials, equipment, staff and opportunity for peoples' participation go in strong favour for application of Geoact $\mathrm{Ca}-5$ to counter the global warming. As concentration of the $\mathrm{CO}_{2}$ is maximum close to ground and in lower elevations it offers an opportunity to eradicate by application of Geoact $\mathrm{Ca}$-5. Several manifestations can be devised to eradicate the $\mathrm{CO}_{2}$ in enclosures etc. to eradicate pollutions. Large scale applications can be exercised by people's participation.

\section{Acknowledgement}

Grateful thanks are expressed to Professor Nageswar Dube, Department of Earth Sciences. Eritrea Institute of Technology, Mainefhi Asmara, Eritrea, for reading the manuscript and offering valuable suggestions for improvement.

\section{References}

1. Baskin, Yvonne (1996) Engineering the globe: A fix for the Environment Science Year 1996. The World Book, Annual Science Supplement 145-157.

2. Yadav RC (2013). Combating acid rain: Physically based process and product Hydrology: Current Research 4: 1.

3. Mathew K.M (1996) Manorma year Book. Malyalam Manorma.

4. .http:/en.wikipedia.org/wiki/acid rain):

5. Seinfeld JH , Pandis SN (1998) Atmospheric Chemistry and Physics. From Air Pollution to Climate Change (2ndedn). John wiley and Sons.

6. Blank LT, Tarquin AJ (2011) Engineering Economy (5thedn) Mcgraw Hill Education, New York.

7. http:/en.wikipedia.org/wiki/diffusion of innovation.

8. Alin Simone, Johnson Thomas (2007) Carbon loss from lakes. Global BioGeo Chemice 21. GB 3002(2007)

9. Yadav RC (2007) Entrap and eradicate the $\mathrm{CO}_{2}$ : A new method for reducing global warming. WSEA conference on environment Athen. (Pear Reviewed and accepted for presentation)

10. Mosier A, Schiemel D, Valentine D, Bonson K, Parton W (1991) Methane and nitrous oxide fluxes in native fertilized and cultivated grasslands. Nature 350 330-332.

11. Majumdar D, Pathak H, Kumar S, Jain MC (2002) Nitrous oxide emission from a sandy loam inceptisol under irrigated wheat in India as influenced by different nitrification inhibitors. Agriculture Ecosystem and Environment.91: 283-293.

12. Streigi RG. MacConnaughey TA, Thorestenson DC, Weeks EP, Woodward JC (1992) Consumption of atmospheric methane by desert soils. Nature: 357 : 145-147.

13. Lima IBT, Ramos FM, Bambace AWL, Reinaldo RR (2007) Methane emission from the large dams as renewable nenergy resources: A developing nation perspective. Mitig Adapt Stra Glob Change 13:193-206.

14. Blyth FGH, de Frestas MH. (1994) A geology for Engineers Seventh (edn.) ELBS.

15. Bronwyn, HH, Helmens C (2011) Innovation and diffusion of clean green technology. NBER, Paper No.: 16920

16. Robinson JC, Smith MD (2008) Cost-reducing innovation in health care. Health Aff (Millwood) 27: 1353-1356. 